\title{
CD6 expression has no effect on atherosclerosis in apolipoprotein E-deficient mice
}

\author{
Juying $\operatorname{Han}^{1 \dagger}$, Gospel Enyindah-Asonye ${ }^{2 \dagger}$, Feng Lin ${ }^{2 *}$ and Jonathan D. Smith ${ }^{1 *}$ (])
}

\begin{abstract}
Objective: To determine if deficiency of $\mathrm{CD6}$, a cell surface protein on lymphocytes that alters natural antibody production, increases atherosclerosis in ApoE-deficient mice fed a chow or a western-type diet.

Results: We compared cholesterol levels, IgM, B1a cells, and aortic root lesion areas in ApoE-deficient vs. CD6/ApoE double deficient mice. Feeding the high-fat western type diet increased all parameters, except for B1a cell numbers decreased. Sex also had an effect on many parameters with males having increased body weights, higher high density lipoprotein cholesterol, higher B1a cells, but smaller atherosclerotic lesions if chow fed mice; however, this sex effect on atherosclerosis was absent in mice fed the western-type diet. CD6 deficiency had no effect on atherosclerosis in both male and female mice on either diet. Thus, loss of CD6 on lymphocytes did not lead to expected reductions in B1a cells and protective lgM levels, and in turn did not alter atherosclerosis in mice.
\end{abstract}

Keywords: B1a cells, Natural IgM, Atherosclerosis, CD6

\section{Introduction}

Atherosclerosis is a chronic inflammatory disease of the artery wall as well as the leading cause of heart attacks and strokes, and B cell subsets can alter atherosclerosis pathogenesis [1-3]. Previous studies have uncovered a protective role for the B1a cells in atherosclerosis [4-6]. Therefore, a better understanding of molecules restricted to B1a cells may lead to the development of novel therapeutics against atherosclerosis.

B cells can be divided into B1 and B2 subtypes based on their developmental origin, function and phenotypic markers [7, 8]. B1 cells can be further divided into B1a, CD5 positive, and B1b, CD5 negative, subsets $[9,10]$. B1a cells spontaneously secrete natural IgM which is atheroprotective in splenectomized apolipoprotein $\mathrm{E}$

*Correspondence: linf2@ccf.org; smithj4@ccf.org

†Juying Han and Gospel Enyindah-Asonye contributed equally to this work

${ }^{1}$ Department of Cellular \& Molecular Medicine, Lerner Research Institute, Cleveland Clinic, 9500 Euclid Avenue, Cleveland, OH, USA

2 Department of Immunology, Lerner Research Institute, Cleveland Clinic, 9500 Euclid Avenue, Cleveland, OH, USA
(apoE)-deficient mice [11]. These mice are susceptible to atherosclerosis in association with reduced B1a cells/ natural IgM titers, but display amelioration of atherosclerosis following reconstitution with $\mathrm{B} 1 \mathrm{a}$ or with purified natural IgM from naïve wildtype mice, but not with B2 cells $[5,12]$.

CD6 is primary expressed on $\mathrm{T}$ cells and a subset of $B$ cells in humans [13-15]. In mouse B1 cells, CD6 is only expressed in non-bone marrow and peritoneal $\mathrm{B} 1 \mathrm{a}$ subsets [16]. CD6 is important for B1a cell homeostasis and natural IgM levels in mice. CD6 deficiency resulted in reduced serum titers of natural IgM and reduced B1a cells in select-tissue compartments [16]. CD6-deficient mice are also protected from natural IgM-mediated intestinal ischemia reperfusion-induced injury [16].

We generated the double knockout (DKO) mouse model of CD6 deficiency (CD6-/-) and apolipoprotein E deficiency (apoE-/-) on the DBA atherosclerosissensitive genetic background [17] in order to determine if CD6 expression is atheroprotective due to increased production of natural IgM. 


\section{Main text \\ Methods}

Generation of CD6 and ApoE double knockout mice

ApoE-/- mice [18] were previously backcrossed onto the DBA/2 background for $>20$ generations [17]. CD6-/- mice were originally made at Bristol-Myers Squibb and backcrossed onto the DBA/1 background for $>12$ generations [19]. These strains were intercrossed to generate F1 mice hemizygous for both ApoE and CD6, which were bred back to DBA/2 ApoE-/- mice to select ApoE-/- CD6+/- progeny. These ApoE-/- CD6+/mice were brother-sister mated to generate $\mathrm{CD} 6+/+$, CD6+/-, and CD6-/- mice on the ApoE-/- background. We used the $\mathrm{CD} 6+/+$ and $\mathrm{CD} 6-/-$ mice in these studies.

\section{Atherosclerosis assay}

ApoE-/- CD6+/+ (KO) and ApoE-/- CD6-/- (double knockout, DKO) mice were fed a chow diet (Teklad 2018) or a western-type diet (WTD, Teklad 88137, 21\% milk fat $/ 0.15 \%$ cholesterol (wt:wt), starting at 8 weeks of age). Mice were sacrificed by $\mathrm{CO}_{2}$ inhalation at 16 weeks of age. Whole blood was collected from the retro-orbital plexus to obtain plasma. Quantitative assessment of atherosclerosis in the aortic root was performed as previously described [20]. Lesion areas were quantified as the mean value in six sections at $80 \mu \mathrm{m}$ intervals using Image Pro software (Media Cybernetics). We analyzed $14 \mathrm{KO}$ and $6 \mathrm{DKO}$ male mice and $16 \mathrm{KO}$ and $10 \mathrm{DKO}$ female mice on chow diet; and, $8 \mathrm{KO}$ and $6 \mathrm{DKO}$ male mice and $5 \mathrm{KO}$ and $10 \mathrm{DKO}$ female mice on WTD. Atherosclerosis assays of three female $\mathrm{KO}$ on chow and one DKO on WTD diet were not able to be quantified due to improper sectioning through the aortic root, yielding 13 and 9 samples respectively.

\section{Determination of total cholesterol and HDL-cholesterol}

$30 \mu \mathrm{l}$ of plasma was mixed with $30 \mu \mathrm{l}$ of $\mathrm{KBr}$ (density of $1.12 \mathrm{~g} / \mathrm{ml}$ ), placed into $0.2 \mathrm{ml}$ tubes and centrifuged at $70,000 \mathrm{rpm}$ for $16 \mathrm{~h}$ in an S100-AT3 rotor (Thermo Scientific). The bottom $30 \mu$ layer with a density $>1.063$ was used to determine HDL-cholesterol, and whole plasma was used for total cholesterol levels, both run with technical duplicates using the Cholesterol Liquicolor kit (StanBio Laboratory, catalog\#1010-225). Missing values were due to insufficient plasma recovery or poor ultracentrifugation.

\section{B cell population determined by flow cytometry}

Mouse fresh spleens were removed after PBS perfusion. Single-cell suspensions were prepared by slicing the excised spleen into small pieces and passage through a strainer. Following centrifugation of the cell suspension, the cell pellet was incubated with red blood cell lysing solution for $3 \mathrm{~min}$. The splenocytes were washed with PBS and incubated with the following antibodies: antiCD19 (catalog\#115532); anti-CD43 (catalog\#143206); anti-CD5 (catalog\#100626); and, anti-CD6 clone 34 (prepared in the Lin laboratory). All antibodies except for anti-CD6 were acquired from BioLegend and diluted $1 / 100$. Cells were stained in FACS buffer, and expression of cell surface markers was acquired on the FACSCalibur flow cytometer. Flow cytometer data were analyzed using Flowjo software. Missing values were due to insufficient blood recovery or no access to the flow cytometer when the fresh stained cells were prepared.

\section{Plasma IgM and phosphorylcholine specific IgM (PC-IgM) assays}

Total IgM were detected by coating 96-well plates with $0.34 \mu \mathrm{g} / \mathrm{ml}$ rabbit anti-mouse $\operatorname{IgM}+\operatorname{IgG}(\mathrm{H}+\mathrm{L})$ (Jackson ImmunoResearch, catalog\#315-005-048). Plasma samples (diluted 1/1000) were added to the plates. Bound antibodies were detected using goat anti-mouse IgM HRP (Southern Biotech, catalog\#1021-05). For the detection of PC-IgM, plates were coated with $10 \mu \mathrm{g} / \mathrm{ml}$ PC-BSA (Biosearch Technologies, catalog\#PC-1011-10). Samples (diluted 1/1000) were added and bound PC-IgM antibodies were detected using goat anti-mouse IgM-HRP (Southern Biotech, catalog\#1021-05). The ELISA was developed using TMB substrate (Pierce, catalog\#34021). $\mathrm{H}_{2} \mathrm{SO}_{4}$ was added to stop the reaction and absorbance at $450 \mathrm{~nm}$ was measured. Missing values were due to insufficient plasma recovery.

\section{Statistical analyses}

All phenotypic data was analyzed using a number code that did not specify genotype or sex, thus data acquisition was blinded. All data were normally distributed passing the KS and/or D'Agostino and Pearson normality tests, and parametric statistics were used. Results are expressed as the mean $\pm \mathrm{SD}$. T-tests were used for comparisons of $\mathrm{KO}$ vs DKO phenotypes within one diet and sex. Two way ANOVAs with Bonferroni correction for multiple comparisons were performed to analyze diet and sex effects simultaneously with genotype effects. $P$ values $<0.05$ were considered significant. Statistical analyses were performed using Prism v5.04 software (GraphPad).

\section{Results}

\section{Characterization of DKO mice}

We crossed CD6-/- mice on the DBA/1 background to ApoE-/- on the closely related DBA/2 background, and two groups of mice were studied: $\mathrm{KO}$ and DKO. As sex is an important biological variable, we analyzed all phenotypes separately by sex. 
The genotype and diet effects in male mice are shown in Table 1. On the chow diet, there were no significant differences between the $\mathrm{KO}$ and DKO for any of the measured phenotypes. On the WTD, total IgM levels were significantly higher in the DKO vs. KO mice, but no other measures were significantly different. We looked for diet and genotype effects using two-way ANOVA. WTD had significant effects on all of the phenotypes, increasing body weight, total and HDL cholesterol, IgM, PC-IgM, and lesion area, while decreasing B1a cells. The genotype effect was limited to PC-IgM, which was higher in the DKO mice. We found no significant interaction between the diet and genotype effects in the male mice.
The genotype and diet effects in female mice are shown in Table 2. On the chow diet, there were no significant differences between the $\mathrm{KO}$ and DKO for any of the measured phenotypes. On the WTD, B1a cells was significantly decreased in the DKO vs. KO mice, but no other measures were significantly different. In the twoway ANOVA analysis, WTD had significant effects on increasing body weight, total cholesterol, PC-IgM, and lesion area, while decreasing HDL-C and B1a cells. The genotype effect was limited to B1a cell number, which were lower in the DKO mice. We found a significant interaction between the diet and genotype effects for both PC-IgM and lesion area in the female mice.

Table 1 CD6 genotype and diet effects in male mice

\begin{tabular}{|c|c|c|c|c|c|c|c|c|c|}
\hline \multirow[t]{2}{*}{ Phenotype } & \multicolumn{3}{|l|}{ Chow diet } & \multicolumn{3}{|l|}{ Western type diet } & \multirow{2}{*}{$\begin{array}{l}\text { Diet effect } \\
\text { P value }\end{array}$} & \multirow{2}{*}{$\begin{array}{l}\text { Genotype } \\
\text { P value }\end{array}$} & \multirow{2}{*}{$\begin{array}{l}\text { Interaction } \\
\text { P value }\end{array}$} \\
\hline & Ko & DKO & T-test & Ko & DKO & T-test & & & \\
\hline \multicolumn{10}{|l|}{ Male mice } \\
\hline $\begin{array}{l}\text { Body } \\
\text { weight (g) }\end{array}$ & $28.3 \pm 3.2(14)$ & $28 \pm 1.5(6)$ & N.S & $35.5 \pm 4.0(8)$ & $31.8 \pm 3.4(6)$ & N.S & $<0.0001$ & N.S & N.S \\
\hline $\begin{array}{c}\text { Cholesterol } \\
(\mathrm{mg} / \mathrm{dl})\end{array}$ & $1251 \pm 161.1(10)$ & $1179 \pm 143.1(5)$ & N.S & $2518 \pm 257.5(8)$ & $2876 \pm 507.7(6)$ & N.S & $<0.0001$ & N.S & N.S \\
\hline $\begin{array}{l}\mathrm{HDL}-\mathrm{C}(\mathrm{mg} / \\
\quad \mathrm{dl})\end{array}$ & $86 \pm 26.3(8)$ & $79 \pm 28.2(5)$ & N.S & $146 \pm 88.4(8)$ & $130.2 \pm 63.7(6)$ & N.S & 0.026 & N.S & N.S \\
\hline $\lg M(\mu \mathrm{g} / \mathrm{ml})$ & $55.6 \pm 33.5(14)$ & $54.3 \pm 27.1(6)$ & N.S & $70.2 \pm 29.8(8)$ & $102.3 \pm 16.3(6)$ & 0.036 & 0.006 & N.S & N.S \\
\hline $\begin{array}{l}\text { Pc-lgM (OD } \\
\text { read) }\end{array}$ & $0.15 \pm 0.1(14)$ & $0.21 \pm 0.11(5)$ & N.S & $0.51 \pm 0.22(8)$ & $0.7 \pm 0.21(6)$ & N.S & $<0.0001$ & 0.042 & N.S \\
\hline $\begin{array}{l}\text { B1a cells (\% } \\
\text { of total } \\
\text { cells) }\end{array}$ & $4.17 \pm 1.43(10)$ & $3.96 \pm 0.8(5)$ & N.S & $1.8 \pm 1.22(5)$ & $2.93 \pm 1.36(6)$ & N.S & 0.0026 & N.S & N.S \\
\hline $\begin{array}{l}\text { Lesion area } \\
\qquad\left(\mu m^{2}\right)\end{array}$ & $114,960 \pm 52,300(14)$ & $95,595 \pm 43,576(6)$ & N.S & $507,311 \pm 209,049(8)$ & $674,382 \pm 292,443(6)$ & N.S & $<0.0001$ & N.S & N.S \\
\hline
\end{tabular}

Table 2 CD6 genotype and diet effects in female mice

\begin{tabular}{|c|c|c|c|c|c|c|c|c|c|}
\hline \multirow[t]{2}{*}{ Phenotype } & \multicolumn{3}{|l|}{ Chow diet } & \multicolumn{3}{|l|}{ Western type diet } & \multirow{2}{*}{$\begin{array}{l}\text { Diet effect } \\
\text { P value }\end{array}$} & \multirow{2}{*}{$\begin{array}{l}\text { Genotype } \\
\text { P value }\end{array}$} & \multirow{2}{*}{$\begin{array}{l}\text { Interaction } \\
\text { P value }\end{array}$} \\
\hline & KO & DKO & T-test & KO & DKO & T-test & & & \\
\hline \multicolumn{10}{|l|}{ Female mice } \\
\hline $\begin{array}{l}\text { Body } \\
\text { weight } \\
\text { (g) }\end{array}$ & $23.9 \pm 2.5(16)$ & $23.4 \pm 2.9(10)$ & N.S & $28.4 \pm 5.2(5)$ & $25.9 \pm 3.5(10)$ & N.S & 0.003 & N.S & N.S \\
\hline $\begin{array}{l}\text { Cholesterol } \\
(\mathrm{mg} / \mathrm{dl})\end{array}$ & $1064 \pm 159.8(13)$ & $1127 \pm 240.9(7)$ & N.S & $2338 \pm 332.4(5)$ & $2040 \pm 473.7(10)$ & N.S & $<0.0001$ & N.S & N.S \\
\hline $\begin{array}{l}\mathrm{HDL}-\mathrm{C}(\mathrm{mg} / \\
\quad \mathrm{dl})\end{array}$ & $56.6 \pm 14.4(10)$ & $53.8 \pm 16.2(7)$ & N.S & $40.5 \pm 27.6(3)$ & $44.2 \pm 24.0(7)$ & N.S & N.S & N.S & N.S \\
\hline $\operatorname{lgM}(\mu \mathrm{g} / \mathrm{ml})$ & $56.8 \pm 47.4(14)$ & $65.4 \pm 34.1(10)$ & N.S & $74.63 \pm 21(5)$ & $63.8 \pm 24.4(9)$ & N.S & N.S & N.S & N.S \\
\hline $\begin{array}{l}\text { Pc-lgM (OD } \\
\text { read) }\end{array}$ & $0.31 \pm 0.2(14)$ & $0.18 \pm 0.13(10)$ & N.S & $0.54 \pm 0.25(5)$ & $0.85 \pm 0.46(10)$ & N.S & $<0.0001$ & N.S & 0.032 \\
\hline $\begin{array}{l}\text { B1a cells (\% } \\
\text { of total } \\
\text { cells) }\end{array}$ & $3.16 \pm 0.58(7)$ & $2.49 \pm 1.23(6)$ & N.S & $1.97 \pm 0.54(4)$ & $1.29 \pm 0.45(7)$ & 0.049 & 0.0013 & 0.048 & N.S \\
\hline $\begin{array}{l}\text { Lesion area } \\
\qquad\left(\mu \mathrm{m}^{2}\right)\end{array}$ & $129,119 \pm 59,493(13)$ & $185,825 \pm 108,327(10)$ & N.S & $596,416 \pm 233,199(5)$ & $466,142 \pm 165,955(9)$ & N.S & $<0.0001$ & N.S & 0.026 \\
\hline
\end{tabular}


Sex effects were examined combining both genotypes in mice fed the chow and WTD (Table 3). On chow diet, males had significantly higher body weights, HDL-C, and $\mathrm{B} 1 \mathrm{a}$ cells, but lower lesion areas, the latter finding is common for aortic root lesion area in apoE-/- mice [21]. On the WTD, males had significantly higher body weights, total cholesterol, HDL-C, and a non-significant trend towards higher B1a cell number and lesion area.

\section{Discussion}

We generated ApoE/CD6 DKO mice to address the role of CD6 in cardiovascular disease given the recent focus of CD6 as a therapeutic target for the treatment of several autoimmune diseases [16, 19, 22-25]. We hypothesized that the DKO mice would have larger lesions due to decreased B1a cells and natural IgM. In this study we report that DKO vs. KO did not significantly alter aortic root atherosclerosis in either male or female mice fed the chow or WTD. There were no significant differences between the two genotypes for most of the measured phenotypes; however, feeding WTD had significant effects on almost all of the phenotypes, and there were also many sex effects. Thus, the lack of altered atherosclerosis in the DKO mice indicates that CD6 therapeutic potential may not extend to cardiovascular-related disease.

We previously reported that splenic B1a cells and total IgM were decreased in chow diet-fed CD6-/mice on the DBA/1 background [16]. After breeding to hyperlipidemic ApoE-/- mice on the DBA/2 background, B1a cells were not significantly changed in male mice on either diet, or in female mice on the chow diet, but were significantly decreased in female mice fed the WTD. Baseline splenic B1a cell levels were higher in ApoE- $-1-$ mice $(\sim 2-4 \%)$ compared to our prior study in wild type DBA/1 mice (1.4\%), and perhaps the loss of CD6 was not as effective in reducing B1a cells in the context of elevated B1a cells in hyperlipidemic

Table 3 Sex effects in mice fed chow and western-type diets

\begin{tabular}{lcc}
\hline Phenotype & $\begin{array}{l}\text { Sex effect chow } \\
\text { P value }\end{array}$ & $\begin{array}{l}\text { Sex effect WTD } \\
\text { P value }\end{array}$ \\
\hline Body weight $(\mathrm{g})$ & $<0.0001$ & 0.0002 \\
Cholesterol $(\mathrm{mg} / \mathrm{dl})$ & 0.07 & $<0.0001$ \\
$\mathrm{HDL}-\mathrm{C}(\mathrm{mg} / \mathrm{dl})$ & 0.0018 & 0.0013 \\
$\mathrm{IgM}(\mu \mathrm{g} / \mathrm{ml})$ & 0.61 & 0.08 \\
Pc-lgM (OD read) & 0.19 & 0.49 \\
B1a cells $(\%$ of total cells) & 0.0006 & 0.1 \\
Lesion area $\left(\mu \mathrm{m}^{2}\right)$ & 0.027 & 0.49 \\
\hline
\end{tabular}

mice. The decrease in B1a cells in CD6-/- mice on the DBA/1 background was associated with moderate decreases in total IgM and PC-IgM [16]; however, with little effect on B1a cells in the current study, we found no effects on IgM levels, except for a moderate increase in total IgM in the male DKO mice fed the WTD. Previously, adoptive transfer of $\mathrm{B} 1 \mathrm{a}$ cells into splenectomized apoE-1- mice fed the WTD increased B1a cells, IgM and slightly decreased lesion area [4]. However, CD6deficiency did not significantly alter these parameters, having no effect on the protective PC-IgM levels; and, we did not observe an effect on atherosclerosis in the DKO mice. All IgM is not atheroprotective, only a subset of natural IgM has this property. Natural antibody PC-IgM has been reported to be protective in human cardiovascular disease and atherosclerosis [26, 27]. Further studies will be required to unravel the reasons for $\mathrm{B} 1 \mathrm{a}$-cell related phenotypic differences between $\mathrm{KO}$ and DKO mice.

Feeding the WTD led to significant effects in $\mathrm{KO}$ and DKO male mice, increasing body weight, total cholesterol, HDL-C, IgM, PC-IgM, and lesion area, while decreasing B1a cells. Similar effects of the WTD were seen in the female mice, although HDL-C and IgM levels trended up but were not significant. Thus, this challenge with the WTD uncovered an unexpected inverse association between endogenous B1a cells in the spleen and IgM/Pc-IgM levels, regardless of CD6 genotype. These findings were novel given that the effect of diet on CD6 mediated function has not been previously reported. However, B1a cell-mediated function has been reported to be influenced by environmental factors [28-31], and diet may contribute to the inverse association between B1a cells and IgM levels.

Sex effects on lipoprotein metabolism and atherosclerosis in mice are commonly observed, but in the opposite direction of what is seen in humans [21]. Aortic root lesion areas were greater in female than male mice that were fed the chow diet. However, this sexeffect was not found in the larger lesions observed after feeding the WTD, as the high total cholesterol values in WTD-fed mice may override this effect.

\section{Limitations}

This study used CD6 and ApoE deficient mice that were on slightly different genetic backgrounds (DBA/1 and DBA/2, respectively), which could alter our results. A potential way to address this limitation in future studies could be to use anti-CD6 neutralizing antibody treatment in an inbred mouse model of atherosclerosis. 


\section{Abbreviations}

ApoE: apolipoprotein E; KO: ApoE knockout; DKO: ApoE/CD6 double knockout; WTD: western-type diet; PC-IgM: phosphorylcholine specific IgM; HDL-C: HDL cholesterol.

\section{Authors' contributions}

$\mathrm{JH}$ and GEA performed all of the experiments, performed statistical analyses, and drafted the manuscript. JS and FL helped design the studies, performed statistical analyses, edited the manuscript, and acquired funding. All authors read and approved the final manuscript.

\section{Acknowledgements}

Not applicable.

\section{Competing interests}

The authors declare that they have no competing interests.

\section{Availability of data and materials}

The datasets generated and/or analyzed during the current study are available from the corresponding author on reasonable request.

\section{Consent for publication}

Not applicable.

\section{Ethics approval and consent to participate}

All mouse studies were approved by the Cleveland Clinic Institutional Animal Care and Use Committee.

\section{Funding}

This work was supported by the National Institutes of Health Grant P01 HL029582 to J.D.S

\section{Publisher's Note}

Springer Nature remains neutral with regard to jurisdictional claims in published maps and institutional affiliations.

Received: 9 February 2018 Accepted: 24 March 2018

Published online: 03 April 2018

\section{References}

1. Gistera A, Hansson GK. The immunology of atherosclerosis. Nat Rev Nephrol. 2017;13(6):368-80.

2. Ketelhuth DF, Hansson GK. Adaptive response of T and B Cells in atherosclerosis. Circ Res. 2016;118(4):668-78.

3. Srikakulapu P, McNamara CA. B cells and atherosclerosis. Am J Physiol Heart Circ Physiol. 2017;312(5):H1060-7.

4. Hosseini H, Li Y, Kanellakis P, Tay C, Cao A, Tipping P, Bobik A, Toh BH, Kyaw T. Phosphatidylserine liposomes mimic apoptotic cells to attenuate atherosclerosis by expanding polyreactive IgM producing B1a lymphocytes. Cardiovasc Res. 2015:106(3):443-52.

5. Kyaw T, Tay C, Krishnamurthi S, Kanellakis P, Agrotis A, Tipping P, Bobik A, Toh $\mathrm{BH}$. B1a B lymphocytes are atheroprotective by secreting natural IgM that increases IgM deposits and reduces necrotic cores in atherosclerotic lesions. Circ Res. 2011:109(8):830-40.

6. Kyaw T, Tipping P, Bobik A, Toh BH. Protective role of natural IgM-producing B1a cells in atherosclerosis. Trends Cardiovasc Med. 2012;22(2):48-53.

7. Baumgarth $\mathrm{N}$. The double life of a B-1 cell: self-reactivity selects for protective effector functions. Nat Rev Immunol. 2011;11(1):34-46.

8. Hardy RR, Hayakawa K. Positive and negative selection of natural autoreactive B cells. Adv Exp Med Biol. 2012;750:227-38.

9. Hardy RR, Hayakawa K. Selection of natural autoreactive B cells. Clin Exp Rheumatol. 2015;33(4 Suppl 92):S80-6.

10. Hardy RR, Hayakawa K. Perspectives on fetal derived CD5+ B1 B cells. Eur J Immunol. 2015;45(11):2978-84.

11. Rezende $A B$, Neto NN, Fernandes LR, Ribeiro AC, Alvarez-Leite Jl, Teixeira $\mathrm{HC}$. Splenectomy increases atherosclerotic lesions in apolipoprotein $\mathrm{E}$ deficient mice. J Surg Res. 2011;171(2):e231-6.
12. Wardemann $\mathrm{H}$, Boehm T, Dear N Carsetti R. B-1a B cells that link the innate and adaptive immune responses are lacking in the absence of the spleen. J Exp Med. 2002;195(6):771-80.

13. Alonso R, Buors C, Le Dantec C, Hillion S, Pers JO, Saraux A, Montero E, Marianowski R, Loisel S, Devauchelle $V$, et al. Aberrant expression of CD6 on B-cell subsets from patients with Sjogren's syndrome. J Autoimmun. 2010;35(4):336-41.

14. Brown MH. CD6 as a cell surface receptor and as a target for regulating immune responses. Curr Drug Targets. 2016;17(6):619-29.

15. Hernandez P, Moreno E, Aira LE, Rodriguez PC. Therapeutic targeting of CD6 in autoimmune diseases: a review of cuban clinical studies with the antibodies IOR-T1 and itolizumab. Curr Drug Targets. 2016;17(6):666-77.

16. Enyindah-Asonye G, Li Y, Xin W, Singer NG, Gupta N, Fung J, Lin F. CD6 receptor regulates intestinal ischemia/reperfusion-induced injury by modulating natural lgM-producing B1a cell self-renewal. J Biol Chem. 2017:292(2):661-71

17. Hsu J, Smith JD. Genetic-genomic replication to identify candidate mouse atherosclerosis modifier genes. J Am Heart Assoc. 2013:2(1):e005421.

18. Plump AS, Smith JD, Hayek T, Aalto-Setala K, Walsh A, Verstuyft JG, Rubin EM, Breslow JL. Severe hypercholesterolemia and atherosclerosis in apolipoprotein E-deficient mice created by homologous recombination in ES cells. Cell. 1992;71(2):343-53.

19. Li Y, Singer NG, Whitbred J, Bowen MA, Fox DA, Lin F. CD6 as a potential target for treating multiple sclerosis. Proc Natl Acad Sci USA 2017:114(10):2687-92.

20. Baglione J, Smith JD. Quantitative assay for mouse atherosclerosis in the aortic root. Methods Mol Med. 2006;129:83-95.

21. Robinet P, Milewicz DM, Cassis LA, Leeper NJ, Lu HS, Smith JD. Consideration of sex differences in design and reporting of experimental arterial pathology studies-statement from ATVB council. Arterioscler Thromb Vasc Biol. 2018:38(2):292-303.

22. Aira LE, Lopez-Requena A, Fuentes D, Sanchez L, Perez T, Urquiza A, Bautista H, Falcon L, Hernandez P, Mazorra Z. Immunological and histological evaluation of clinical samples from psoriasis patients treated with antiCD6 itolizumab. MAbs. 2014;6(3):783-93.

23. Rodriguez PC, Prada DM, Moreno E, Aira LE, Molinero C, Lopez AM, Gomez JA, Hernandez IM, Martinez JP, Reyes Y, et al. The anti-CD6 antibody itolizumab provides clinical benefit without lymphopenia in rheumatoid arthritis patients: results from a 6-month, open-label phase I clinical trial. Clin Exp Immunol. 2017. https://doi.org/10.1111/cei.13061.

24. Rodriguez PC, Torres-Moya R, Reyes G, Molinero C, Prada D, Lopez AM, Hernandez IM, Hernandez MV, Martinez JP, Hernandez X, et al. A clinical exploratory study with itolizumab, an anti-CD6 monoclonal antibody, in patients with rheumatoid arthritis. Results Immunol. 2012:2:204-11.

25. Singh V. Clinical outcome of a novel anti-CD6 biologic itolizumab in patients of psoriasis with comorbid conditions. Dermatol Res Pract. 2016:2016:1316326.

26. Fiskesund R, Su J, Bulatovic I, Vikstrom M, de Faire U, Frostegard J. IgM phosphorylcholine antibodies inhibit cell death and constitute a strong protection marker for atherosclerosis development, particularly in combination with other auto-antibodies against modified LDL. Results Immunol. 2012;2:13-8.

27. Shaw PX, Horkko S, Chang MK, Curtiss LK, Palinski W, Silverman GJ Witztum JL. Natural antibodies with the T15 idiotype may act in atherosclerosis, apoptotic clearance, and protective immunity. J Clin Invest. 2000;105(12):1731-40.

28. Jennbacken K, Stahlman S, Grahnemo L, Wiklund O, Fogelstrand L. Glucose impairs B-1 cell function in diabetes. Clin Exp Immunol. 2013;174(1):129-38.

29. Shaikh SR, Haas KM, Beck MA, Teague $H$. The effects of diet-induced obesity on B cell function. Clin Exp Immunol. 2015;179(1):90-9.

30. Wu YY, Georg I, Diaz-Barreiro A, Varela N, Lauwerys B, Kumar R, Bagavant H, Castillo-Martin M, El Salem F, Maranon C, et al. Concordance of increased B1 cell subset and lupus phenotypes in mice and humans is dependent on BLK expression levels. J Immunol. 2015;194(12):5692-702.

31. Yurino $H$, Ishikawa $S$, Sato T, Akadegawa $K$, Ito T, Ueha S, Inadera $H$, Matsushima K. Endocrine disruptors (environmental estrogens) enhance autoantibody production by B1 cells. Toxicol Sci. 2004;81(1):139-47. 